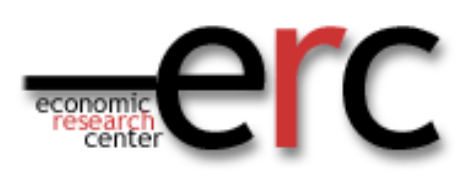

ERC Working Paper in Economic 04/08 August 2004

\title{
Private Tutoring Expenditures in Turkey
}

\author{
Aysit Tansel \\ Department of Economics \\ Middle East Technical University \\ 06531 Ankara. Turkey \\ e-mail: atansel@metu.edu.tr \\ Fatma Bircan \\ Department of Economics \\ Middle East Technical University \\ 06531 Ankara. Turkey \\ e-mail: bircan@metu.edu.tr
}




\title{
Private Tutoring Expenditures In Turkey*
}

by

\author{
Aysit Tansel \\ Department of Economics \\ Middle East Technical University \\ 06531 Ankara. Turkey \\ e-mail: atansel@metu.edu.tr \\ Fatma Bircan \\ Department of Economics \\ Middle East Technical University \\ 06531 Ankara. Turkey \\ e-mail: bircan@metu.edu.tr
}

March. 2004

Key Words: Private tutoring, education, demand for education

JEL classification: I20. I21. I22. R20

\begin{abstract}
This is the first study on private tutoring in Turkey. Private tutoring especially for the purpose of preparing for the competitive university entrance examination is an important, widespread phenomenon in Turkey. Private tutoring centers are commonly referred to as "dersane" in Turkish. This study first gives an overview of private tutoring centers. Next, it examines the determinants of private tutoring expenditures in Turkey using the results of the 1994 Household Expenditure Survey. The determinants examined within a Tobit model framework include total household expenditure, education levels of parents and other household characteristics. Such analysis of the household behavior of attempting to provide better education to their children will highlight the determinants of the demand for education and the intergenerational transfers in Turkey.

*This article is based on a chapter of Fatma Bircan's Ph.D. thesis prepared under the supervision of Aysit Tansel at the Department of Economics, Middle East Technical University. An earlier version of this paper was presented at the erc/METU International Conference in Economics, Ankara, in September 2002. We are grateful to Şefik Yılıdızeli and Ömer Demir, the former and current presidents of the State Institte of Statistics and Murat Karakaş, chief of Income and Expenditure Statistics and his staff Özlem Sarığlu and Sema Alıcı for their kind help in implementing this study. We also thank Middle East Technical University and the State Planning Organization for the OYP grant for this study. Any errors are our responsibility.
\end{abstract}




\section{Introduction}

Private tutoring can be defined as the education outside the formal schooling system where the tutor teaches particular subject(s) in exchange for a financial gain. This definition points to the three properties of the private tutoring. First, it is separate from the formal education as it is an extra curriculum activity. Second, the teacher's supply of knowledge is mainly driven by profit motives. Third, the students' expectations of the tutor are higher than that of a normal school teacher. Students who demand private tutoring believe that their chances of successfully moving through the educational system will be increased by private tutoring. Otherwise, they would satisfy themselves with the formal school courses which are usually provided free of charge by the public.

Private tutoring has been a well-spread, large-scale industry in several countries in the world, especially in East Asia. Bray and Kwock (2003) give a review of the examples on private tutoring from a wide range of countries ranging from Egypt to Taiwan. The common feature of the educational systems of the countries where the practice of private tutoring is extensive is the existence of competitive entrance examinations to the universities. For example, in South Korea, Greece, Japan and Turkey high school graduates are required to take a nation-wide university entrance examination in order to be selected into a university. In the developing countries, deficiencies in the educational system such as inadequate number of universities, large class sizes and low public educational expenditures are often cited as the reasons for the high demand for private tutoring. As such private tutoring can be regarded as a market response to the mediocrity in the public school system (Kim and Lee, 2001). However, there is a growing demand for private tutoring in many developed countries where such deficiencies are at a minimum or do not exist (Bray 
and Kwock, 2003). In Canada, for example, the demand for private tutoring has grown immensely and became a major business activity over the last decade (Aurini and Davies, 2003). Relatively poor performance of the students from the developed countries in major international academic tests is given as the reason for the growing demand for private tutoring in these countries.

Families who want their children to move successfully from high school to university and then to occupational careers spend more time and money on the informal educational activities (Stevenson and Baker, 1992). Kim and Lee (2001) emphasize that private tutoring is closely related to the economic competence of the families. In this regard, Stevenson and Baker ask if private tutoring is “...an avenue for the transmission of social advantages from parents to their children in the contest for educational credentials?" (p.1643). This implies that it could obscure the educational equity and could diverge economic and social advantages in favor of wealthier households.

The study of private tutoring received little attention in the literature. Lack of official statistics and documentation on private tutoring is one reason for the neglect of the studies in this area. However, educational scientists are now turning attention to this topic. The studies by Bray and Kwock (2003) for Hong-Kong and by Kim and Lee (2001) for South Korea are the recent examples. Bray (2003) considers contra-positive effects of private tutoring.

This article is the first study of private tutoring in Turkey. We examine the general features of the private tutoring in Turkey and estimate a private tutoring expenditure function for the Turkish households. For this purpose, we use the results of the 1994 Household Expenditure Survey conducted by the State Institute of Statistics of Turkey. Our main findings are as follows: Households with higher 
incomes and higher parental educational levels devote more resources on private tutoring. The high income elasticity of private tutoring expenditures implies that private tutoring is considered as a luxury in the consumer's budget. Private tutoring expenditures also increase with the age of the household head but at a decreasing rate. Whether a mother works or not does not significantly affect the level of private tutoring expenditures. Being a single mother who is also the household head is a factor that leads to an increase in private tutoring expenses. Private tutoring expenditures are higher in urban areas compared to the rural areas. However, they are not statistically significantly different between the developed and undeveloped neighborhoods and squatter settlements. This implies that households in urban areas regardless of their socio-economic location spend significantly larger amounts on private tutoring of their children.

The organization of this paper is as follows: Following the introduction, Section 2 provides information about the formal educational system and private tutoring in Turkey. The data used in the empirical analysis is introduced in Section 3. Section 4 discusses the empirical specification of the model. Empirical results based on a Tobit model of private tutoring expenditures are presented in Section 5. Finally, the last section gives the summary and conclusions.

\section{Educational System and Private Tutoring in Turkey Educational System in Turkey}

The formal education in Turkey is mainly provided by the government and includes all school levels from pre-school to higher education. Private education is also available at all levels. Public and Private schools (pre-primary, primary and 
secondary) are under the control of the Ministry of Education while public and private universities are controlled by the Higher Education Council of Turkey. Until 1997, five-year primary school was the only compulsory education. In 1997, compulsory schooling is extended from five to eight-year schooling eliminating the middle schools. Secondary schooling in Turkey takes three or four years and tertiary level education takes two to six years. Although the demand for formal education at primary and secondary levels are met by the public and private schools, the demand for higher education can not be fully satisfied by the existing tertiary education system. In 2003, 1,451,811 high school graduates and senior high school students took the nation-wide competitive entrance examination to the universities. However, only 311,498 applicants were placed at a university program (21.5 percent). 195,139 applicants were placed to distance education programs (14 percent). The distance university in Turkey is one of the largest in the world and absorbs 15 percent of students on average each year.

In 1992, the government initiated the establishment of 25 new universities across the country. In addition to these newly established small city universities, several private universities started to operate also. There were seventy-six public and private universities in total all over the country in 2002. But this number has been quite insufficient to meet the demand for higher education. Therefore, there is a nation-wide university entrance examination since the 1970s to prevent the excess enrollment in the tertiary education. This has caused a great increase in the number of private tutoring centers, which prepare students for this extremely competitive examination.

\section{Private Tutoring in Turkey}


Private tutoring in Turkey takes mainly three different forms. The first type is one-to-one instruction by a privately-paid teacher either at the teacher's house or at the student's house. The second type is provided by school teachers during after hours at school where the students also take formal courses. The third type of private tutoring is undertaken by profit-oriented school-like organizations where professional teachers tutor in a classroom setting. This is called "dersane" in Turkish and it is more common than the other types and the facilities of this sort are spread all over the country. We will refer to them as private tutoring centers. Such centers usually own or rent multi-story buildings in the city centers. Students attend these centers outside formal education hours. These centers provide smaller class sizes, better class materials and improved student-teacher relations compared to the formal schools.

Private tutoring centers grew in number especially during the 1960 s in order to prepare students for the university entrance examination. In 1984, there were 174 such centers in the country. In 1984, a law was passed which recognized them as part of the educational activities. Since then their numbers rapidly grew and reached more than 2100 in 2002 (Private Tutoring Centers Association, 2003). This is close to the number of high schools, which was 2500 in 2002 (Ministry of Education of Turkey, 2003). Today the private tutoring centers operate under the supervision of the Ministry of Education. They also have an association called "OZDEBIR" which stands for "The Private Tutoring Centers Association" with headquarters in Istanbul.

Three main reasons are often cited for attending private tutoring centers. First is to prepare for the university entrance examination. Second is to prepare for the entrance examinations of the special high schools (such as Anatolian High Schools where the medium of instruction is English and Science High Schools) and private high schools. Third is to receive supplementary courses to the formal school courses 
of the basic and secondary education. These reasons make clear that private tutoring centers are examination oriented. They cater to students preparing for the two nationwide examinations. One examination selects the basic education students into special high schools. The second nation-wide examination is the university entrance examination. While there is no statistics on the proportion of basic education students attending private tutoring centers, 35 percent of senior high school students attended them in 2001 (Private Tutoring Centers Association, 2003). It is believed that a larger percentage of high school graduates preparing for the university entrance examination attends them.

Private tutoring centers are expensive and usually beyond the reach of a household with average income. The per-capita income in Turkey was 2,500 US dollars in 2002. The average fee charged by private tutoring centers for preparing to the university entrance examination was approximately 1,300 US dollars in 2002 (Cumhuriyet, 2002). During the 2001-2002 academic year the students preparing for high school examination and the university entrance examination paid in total 263 million US dollars to the private tutoring centers all over the country (Cumhuriyet, 2002). This was 1.44 percent of GDP, while public education expenditures at all levels were 2 percent of GDP in 2002 (Ministry of Education of Turkey, 2003). These figures indicate the importance of private tutoring centers in the educational system of the country. Private rate of return to the university education in Turkey is substantially higher than that to the other levels of schooling. Tansel (1994, 1999 and 2001) provides recent evidence on this. This explains the excess demand for the university education and the need for rationing places by university entrance examination. High school graduates compete for the limited number of places of the university programs. The competition is intense for the highly restricted places at some of the programs of 
the prestigious universities. Graduates of these programs command better job prospects and higher incomes than average. Parents are aware of the high economic returns to the university education. For this reason, they send their children to private tutoring centers in order to increase their chances of success at the university entrance examination. This is usually done with great financial sacrifices. There is also competition to attract students among the private tutoring centers. They advertise the examination achievement results of former tutees. Some private tutoring centers offer lower fees to the students who perform above a certain level in an examination they administer. Those who achieved high are granted discounts in the center's fees.

Private tutoring centers are often in the center of public discussion. In the early 1980s, during the military intervention, there were discussions both in the public and the parliament about closing them down (Private Tutoring Centers Association, 2003) as they were regarded to obscure the equal opportunity in education in favor of children from wealthy families. This concern over the equity issues still prevails in the public discussion today. It is argued that parents who spend enormous sums on private tutoring during high school years of their children pay only nominal tuition fees at the prestigious public universities once their children secure a place at them. This line of argument has been used to rationalize imposing recent tuition fee increases in the public universities.

It is also in the public discussions that attending private tutoring centers disrupts the formal schooling. The subject matters thought in the last year of high school are not explicitly covered in the university entrance examination. For this reason it is quite common that senior high school students, two to three months before the impending university entrance examination, stop going to high school classes and in place concentrate on attending the private tutoring centers. Such practices led the 
Ministry of Education to devise ways to increase the importance of formal schooling over private tutoring. It is only recently announced that high school GPA (grade point average) contributes points towards university entrance along with the result of the university entrance examination. It is planned that only in the 2005 university entrance examination and onwards the subject matters of the last year in high school will be covered. In spite of such measures, private tutoring continues to be a major activity in preparation for the university entrance examination.

\section{Data}

The data used in this study is obtained from the 1994 Household Expenditure Survey collected by the State Institute of Statistics of Turkey. There were 4,279 households who reported educational expenditures of some type. These ranged from the child's school bag expenses to the private school fees. The private tutoring expenditures that we considered included the following. The fees paid to the private tutoring centers, the fees paid for one-to-one private instruction, and the fees paid for private tutoring at schools by the school teachers outside the formal schooling hours ${ }^{1}$. There were 646 households who reported positive private tutoring expenditures by this definition. There were 3,252 households with children between the ages seven and twenty-three who reported positive educational expenditures but zero private tutoring expenditures. So, there were 3,898 observations in total in our data set. We considered the age group seven to twenty-three because the private tutoring could

\footnotetext{
${ }^{1}$ Out of 646 households 70.94 percent paid for the services of private tutoring centers, 9.43 percent paid for one-to-one private instruction and 19.63 percent paid for the tutoring of the schoolteachers. Thus, using services of the private tutoring centers is the most common form of private instruction.
} 
start as early as age seven and be as late as twenty-three for some who may be taking the university entrance examination more than once ${ }^{2}$.

The survey gives the expenditures per household rather than per child so that we have information on private tutoring expenditures per household. The survey took place over the twelve months in 1994. Of the 3,898 households in our sample, 14.6 percent were surveyed in January and 23.2 percent were surveyed in September. These percentages are much larger than in the other months. Thus, households with educational expenditures are well represented in our data as most of the educational expenditures are incurred at the start of the fall and the spring semesters.

Table 1 shows the percentages of the households by income percentiles and proportion of private tutoring expenditures in the total expenditures The percentage of households who devote 1-15 percent of their total expenditure to private tutoring range from about 80 for the first income quartile (the lowest quartile) to about 87 for the forth income quartile (the highest quartile). In other words, a substantial percentage of households (80-87 percent) allocate 1-15 percent of their monthly expenditures $^{3}$ on private tutoring of their children. Bray and Kwock (2003) produced a similar table for the households in Hong-Kong. They found that about 90 percent of households spend about 1-15 percent of their monthly incomes on private tutoring. In their sample, there were no households who spend more than 20 percent of their incomes on private tutoring whereas in our sample the share of private tutoring expenditures in total monthly expenditures ranges from 20 to 50 percent for 7-13 percent of households across all income quartiles.

\footnotetext{
${ }^{2}$ Students may be taking private tutoring in order to supplement the normal school courses, to prepare for the entrance examination to special or private high schools or to prepare for the university entrance examination.

${ }^{3}$ A support staff of our university with a monthly income of only 412 US\$ told us that he has been spending about 30 percent of his monthly income during the past year on private tutoring of his son who is preparing for the university examination.
} 
Table 2 highlights that as the household monthly income increases, participation in private tutoring also increases. According to the State Institute of Statistics data, 73 percent of the private educational expenditures are incurred by the most affluent 20 percent of the households in Turkey in 2002. The total expenditure by the all households was approximately 1.067 billion US dollar during the same year (Milliyet, 2003).

Table 3 shows the percentage of households with zero and positive private tutoring expenditures by parents' level of education. We observe that as the level of education of parents increases the percentage of households with positive private tutoring expenditure steadily goes up.

\section{Empirical Specification}

An Engel curve formulation for private tutoring expenditures is specified using the Tobit model. The private tutoring expenditure, which is the dependent variable, has the value of zero for a number of households. It is, thus, censored at zero. OLS method, which assumes that the dependent variable is normally distributed, is inappropriate in this case. Consistent estimates are obtained by the maximum likelihood estimation of the Tobit model, which is specified as follows.

$$
\begin{aligned}
& Y_{i}^{*}=\beta^{\prime} X+\varepsilon_{i} \\
& Y_{i}=0 \text { if } Y^{*}=0 \\
& Y_{i}=Y_{i}^{*} \text { if } Y_{i}^{*}>0
\end{aligned}
$$

Where $Y_{i}^{*}$ is the latent variable and $Y_{i}$ is its observed counterpart. $\mathrm{X}$ is a vector of personal and household characteristics. $\beta$ is the vector of parameters to be estimated. $\varepsilon$ is the normally and independently distributed error term. There are two marginal effects on the observed Y (Maddala, 1983; McDonald and Moffit, 1980): 


$$
\partial \mathrm{E}(\mathrm{Y}) / \partial \mathrm{X}_{\mathrm{j}}=\mathrm{F}(\mathrm{z}) \beta_{\mathrm{j}}
$$

$$
\partial \mathrm{E}\left(\mathrm{Y}_{\mathrm{i}} \mid \mathrm{Y}_{\mathrm{i}}^{*}>0\right) / \partial \mathrm{X}_{\mathrm{j}}=\beta_{\mathrm{j}}\left(1-(\mathrm{z}) \lambda-\lambda^{2}\right)
$$

Where $\lambda=\mathrm{f}(\mathrm{z}) / \mathrm{F}(\mathrm{z}) ; \mathrm{z}=\beta^{\prime} \mathrm{X}_{\mathrm{i}} / \sigma ; \sigma$ is the standard error of the error term; $\mathrm{f}$ and $\mathrm{F}$ are the probability and the cumulative density functions respectively. These expressions give the marginal effects with and without the information that the observed variable is positive. They are referred to as unconditional and conditional marginal effects respectively.

In the Engel curve literature total expenditure is commonly used as a proxy for income for two reasons (Tansel, 1986). First total expenditure is considered to reflect permanent income better than income itself. Second, it is believed that there are less errors of measurement in total expenditure than in income. Summers (1959) drew attention to the possible simultaneity between individual expenditures and total expenditure leading to biased estimates. Liviatan (1961) suggested using income as an instrumental variable to overcome this bias. Therefore, we first tested for the exogeneity of total expenditure. Exogeneity test in the context of a Tobit model is proposed by Smith and Blundell (1986). The test consists of two stages. In the first stage, total expenditure is regressed on income, which is the instrumental variable. In the second stage, the residuals from the first stage regression are added to the Tobit model of private tutoring expenditures and tested for significance. The null hypothesis of exogeneity is not rejected at five and one percent levels of significance. Therefore, in this study total expenditure is used as an explanatory variable in place of income. The other explanatory variables included are the age and age-square of the household head, the years of education of the household head and the mother, dummy variables indicating whether mother works or not whether mother is single or not, whether 
single mother works or not, whether the household resides in an urban location versus rural location. Then, within an urban location, whether the household resides in a developed street or a squatter settlement. The base is an undeveloped street. A dummy variable indicating whether the household owns the house they live in is also included. The final variable considered is the number of children in the household.

Heteroscedasticity is a frequently encountered problem in Engel curve analysis. It may result from the larger variation in total expenditure among highincome households. Using logarithmic transformation often reduces heteroscedasticity. Therefore, we use the logarithmic transformation of the private tutoring expenditure as well as of the total expenditure. This formulation has the advantage of providing an estimate of the total expenditure elasticity of private tutoring expenditure. Taking logarithm of private tutoring expenditures created a problem since a number of private tutoring expenditures were observed to be zero. In order to overcome this problem we assigned a value of one in place of zero for private tutoring expenditures.

\section{Empirical Results}

Table 4 gives the maximum likelihood estimation results of the Tobit model of private tutoring expenditures and the associated unconditional marginal effects and the marginal effects conditional on positive private tutoring expenditures, according to equations 4 and 5 respectively. Appendix table gives the means and standard deviations of the variables for the groups of households with zero and positive private tutoring expenditures. We now examine the marginal effects of the independent variables in the order they appear in Table 4. 
Since the private tutoring expenditure and total expenditure are both in logarithms the estimates are elasticities. The coefficient estimate of 6.33 is highly significant and represents the total expenditure elasticity of the unobserved private tutoring expenditure index. Unconditional marginal effect of 0.91 is the total expenditure elasticity for all of the households while 1.21 is the total expenditure elasticity for the households with positive private tutoring expenditures. The latter finding implies that private tutoring is a luxury item in the household's budget. As household total expenditure (which is a proxy for permanent income) increases by one percent, private tutoring expenditures increase by more than one percent. Kim and Lee (2001) also found that private tutoring expenditures increase with income after controlling for other factors.

Household head's age and age-square are both statistically significant with the positive and negative signs as expected and as it is also found by Kim and Lee (2001) in Korea. These imply that the private tutoring expenditures increase with the household head's age at a decreasing rate. This result is consistent with the life-cycle expenditure pattern of the household head. Private tutoring expenditures are likely to peak around upper-middle ages when the household head is likely to have school age children.

Household head's and the mother's years of education in households with zero private tutoring expenditures (about 7 and 4 respectively) are lower than in households with positive private tutoring expenditures (about 9 and 7 respectively) (Appendix Table 1). Household head's years of education ${ }^{4}$ and the mother's years of

\footnotetext{
${ }^{4}$ Household head's and mother's years of education are computed from the information on their graduation levels. If the parent is illiterate the variable takes a value of zero; if literate but not graduated from any school, the variable takes a value of two; If the parent has graduated from primary school the variable takes a value of five; If graduated from middle school the variable takes a value of eight; for graduates of general and vocational high schools the variable is assigned a value of eleven;
} 
education are both positive and statistically significant. A year of increase in the head's years of education increases the private tutoring expenditures by 5 percent while a year increase in the mother's education increases the private tutoring expenditures by about 8 percent in the sample with positive tutoring expenditures. It is noteworthy that the effect of mother's education is larger than that of the father's. In most cases the household head is the father except for the cases of single mothers which constitute a quite small proportion in the sample of households. A similar result is also found by Kim and Lee (2001) for Korea. Tansel (2002) found that parents' education is more important for the girls' schooling attainment than that for the boys' in Turkey.

Mother's work status and marital status are each indicated by dummy variables. Results indicate that whether mother works or not does not significantly affect the private tutoring expenditures. It might be conjectured that a working mother has less time to supervise her children and may therefore spend more on private tutoring. Kim and Lee (2001) found ambiguous results for the private tutoring expenditures of the households where the mother works. However, those households where the mother is single spend significantly more on private tutoring in Turkey than households where the mother is married. Kim and Lee found that single mother households do not spend more on private tutoring. An interaction dummy variable where the single mother works is not statistically significant in our results.

Those households who reside in urban areas (locations with population over twenty thousand) spend 66 percent more on private tutoring than households who reside in rural areas. This may be due to better availability of private tutoring centers

for graduates of university the variable is assigned a value of fifteen and finally for those parents with post-graduate degrees, the variable is assigned a value of seventeen. 
in urban locations than in rural areas. Kim and Lee (2001) found a similar result in that those

households who live in high-density residential development areas spent more on private tutoring in Korea. They attributed this effect to the competitive pressures from the close neighborhoods. Besides the urban/rural partition, urban households were classified as those living on a developed street or a squatter settlement each of which was indicated by

a dummy variable with the undeveloped street as the base category. Private tutoring expenditures of those households who live on a developed street or a squatter settlement were not statistically significantly different from those who live on an undeveloped street.

Ownership of houses may capture a wealth effect on private tutoring expenditures. Whether the household owns the house they reside in is indicated by a dummy variable. The coefficient estimate of this variable was statistically insignificant. However, Kim and Lee (2001) found in Korea that households that own houses spend more on private tutoring. The final variable we considered is the number of children. Average number of children is 3.17 in households with no private tutoring expenditures and 2.51 in households with positive private tutoring expenditures (Appendix Table1). An increase in the number of children is found to reduce the private tutoring expenditures. Kim and Lee (2001) found a similar result. This finding is in agreement with the literature, which emphasizes that per capita human capital expenditures decline as the household size increases (Becker and Lewis, 1973; Becker and Tomes, 1976)

\section{Conclusions}


Private tutoring, especially for the purpose of preparing for the competitive university entrance examination, is an important, widespread phenomenon in Turkey. Private tutoring centers functioning for this purpose are commonly referred to as "dersane" in Turkish. Households who send their children to these centers are estimated to spend 1-15 percent of their incomes on average. This is by no means a negligible share of the household budget. This study examines the determinants of private tutoring expenditures in Turkey using the data from the 1994 Household Expenditure Survey carried out by the State Institute of Statistics. A Tobit model framework is used to specify the private tutoring expenditure function since a number of households are observed with zero private tutoring expenditures. Private tutoring expenditure function is described as a function of several of explanatory variables including household total expenditure as it is in the Engel curve analysis.

Total expenditure, which is a proxy for income, is significantly and positively related to the private tutoring expenditures. The results imply that private tutoring is a luxury item in the household's budget. Parental educational levels are also found to be important determinants of private tutoring expenditures with a larger effect for the mother's education than that of the father's education. The positive relationship implies that as the education level of the father and the mother increases the private tutoring expenditures also increase. This has important social implication. It entails inequity in the intergenerational distribution of education. Tansel (2002) also finds that household income and parental educational levels are the most important determinants of educational attainment of children in Turkey.

Private tutoring expenditures increase at a decreasing rate with the age of the household head implying life-cycle considerations. Effect of working mother on private tutoring expenditures is not statistically significant while single mother 
households are found to spend more on private tutoring than households where there is a husband. The effect of working single mother was not statistically significant. Households residing in an urban location spent more than households resident in a rural location. Further, within an urban location living on a developed street or squatter settlement did not statistically differ from living on an undeveloped street in terms of private tutoring expenditures. This implies that households in urban areas regardless of their socio-economic location spend significantly larger amounts on private tutoring of their children. Whether the household owns the house they reside in may entail a wealth effect on private tutoring expenditures. However, it is statistically insignificant. Finally, consistent with the literature on human capital expenditures and the household size, the household private tutoring expenditures are found to decline as the number of children increases.

Private tutoring is an attempt by households of providing better education to their children and higher future incomes. This study sheds lights on the determinants of the private tutoring expenditures. These factors call attention to the demand for education and intergenerational mobility in Turkey.

\section{References:}

Aurini, J. and S. Davies (2003). "The Transformation of Private Tutoring: Education in a Franchise Form." Submission for the Annual Meetings of the CSAA Halifax.

Becker, G. S. and H. G. Lewis. (1973). "On the Interaction Between the Quantity and Quality of Children." Journal of Political Economy 81(2): 279-288.

Becker, G. S. and N. Tomes. (1976). "Child Endowments and the Quantity and Quality of Children.” Journal of Political Economy 84 (412): 143-162.

Bray, M. (2003). Adverse Effects of Private Supplementary Tutoring. International Institute for Educational Planning UNESCO.

Bray. M. and P. Kwock (2003) "Demand for Private Supplementary Tutoring: Conceptual Considerations and Socio-Economic Patterns." Economics of Education Review 22 (2003): 611-620. 
Cumhuriyet Newspaper. August, 3, 2002

Cumhuriyet Newspaper. December, 10, 2002

Hürriyet Newspaper. August, 23, 2003

Kim. S. and Ju-Ho Lee. (2001). "Demand for Education and Developmental State: Private Tutoring in South Korea." Social Science Research Network Electronic Paper Collection: http//papers.ssrn.com/paper.taf?abstract_id=268284

Liviatan. N. (1961). "Errors in Variables and Engel Curve Analysis." Econometrica 29 (3): 336-362.

Maddala. G. (1983). Limited Dependent and Qualitative Variables in Econometrics. Cambridge University Press: New York.

McDonald, J.F. and R.A. Moffitt. (1980) "The Uses of Tobit Analysis" The Review of Economics and Statistics 62 (2): 318-321

Milliyet Newspaper, November, 3, 2003

Ministry of Education of Turkey. (2003). http://meb.gov.tr

Private Tutoring Centers Association. (2003). http://ozdebir.org.tr

Smith, R. and W. R. Blundell. (1986). "An Exogeneity Test for A Simultaneous Equation Tobit Model With An Application to Labor Supply." Econometrica 54 (3): 679-686.

Stevenson, D.L. and D.P. Baker (1992). "Shadow Education and Allocation in Formal Schooling: Transition to University in Japan." American Journal Of Sociology 97 (6): $1639-57$

Summers, R. (1959). "A Note on Least Squares Bias in Household Expenditure Analysis.” Econometrica 27 (1959): 121-126

Tansel, A. (1986). "An Engel Curve Analysis of Household Expenditure in Turkey 1978-79." METU Studies in Development 13 (3-3): 239-257.

Tansel, A. (1994). "Wage Employment, Earnings and Returns to Schooling for Men and Women in Turkey." Economics of Education Review 13(4): 305-320

Tansel, A. (1999). "Public-Private Employment Choice, Wage Differentials and Gender in Turkey." Economic Growth Center Discussion Paper no. 797. New Haven, CT: Yale University.

Tansel, A. (2001). "Self-Employment, Wage Employment and Returns to Schooling by Gender in Turkey." in Labor and Human Capital in the Middle East: Studies of Markets and Household Behavior: 337-367. Ed. By Djavad SalehiIsfahani, Ithaca Press, Reading, UK.

Tansel, A. (2002) "Determinants of Schooling Attainment for Boys and Girls in Turkey: Individual, Household and Community Factors." Economics of Education Review 21: 455-470. 


\begin{tabular}{|c|c|c|c|c||}
\hline \hline \multirow{2}{*}{$\begin{array}{c}\text { TABLE 1: PERCENTAGE OF HOUSEHOLDS BY INCOME PERCENTILES AND PROPORTION OF } \\
\text { PRIVATE TUTORING EXPENDITURES IN TOTAL EXPENDITURES, 1994, TURKEY, }\end{array}$} \\
\hline Percentage of Private Tutoring & 1 st percentile & 2nd percentile & 3rd percentile & 4th percentile \\
\cline { 2 - 5 } $\begin{array}{c}\text { Expenditures in Monthly } \\
\text { Total Expenditures }\end{array}$ & $\mathrm{N}=68$ & $\mathrm{~N}=126$ & $\mathrm{~N}=189$ & $\mathrm{~N}=263$ \\
\cline { 2 - 5 } & $\%$ & $\%$ & $\%$ & $\%$ \\
\hline $1-5$ & 24.64 & 34.13 & 31.75 & 37.26 \\
\hline $5-10$ & 28.99 & 25.40 & 37.57 & 33.46 \\
\hline $10-15$ & 26.09 & 23.81 & 16.40 & 16.35 \\
\hline $15-20$ & 7.25 & 7.94 & 6.35 & 6.08 \\
\hline $20-30$ & 10.14 & 7.94 & 4.76 & 4.56 \\
\hline $30-50$ & 2.90 & 0.79 & 2.12 & 1.9 \\
\hline Total & 100 & 100 & 100 & 100 \\
\hline
\end{tabular}

\begin{tabular}{||l|c|c||}
\hline \multicolumn{2}{|c|}{$\begin{array}{c}\text { TABLE 2: PERCENTAGE OF HOUSEHOLDS WITH ZERO AND POSITIVE PRIVATE TUTORING } \\
\text { EXPENDITURES BY INCOME PERCENTILES. 1994, TURKEY. }\end{array}$} \\
\hline $\begin{array}{l}\text { Income } \\
\text { Percentiles }\end{array}$ & $\begin{array}{c}\text { Households with Zero Private } \\
\text { Tutoring Expenditures }\end{array}$ & $\begin{array}{c}\text { Households with Positive Private } \\
\text { Tutoring Expenditures }\end{array}$ \\
\hline & $\%$ & 10.66 \\
\hline 1st percentile & 27.52 & 19.47 \\
\hline 2nd percentile & 26.56 & 29.21 \\
\hline 3rd percentile & 23.66 & 60.65 \\
\hline 4th percentile & 22.26 & 100 \\
\hline Total & 100 & \\
\hline
\end{tabular}




\begin{tabular}{|c|c|c|c|c|}
\hline \multicolumn{5}{|c|}{$\begin{array}{l}\text { TABLE 3: PERCENTAGE OF HOUSEHOLDS WITH ZERO AND POSITIVE PRIVATE TUTORING } \\
\text { EXPENDITURES BY PARENTS' LEVEL OF EDUCATION. 1994,TURKEY. }\end{array}$} \\
\hline \multirow[t]{2}{*}{\begin{tabular}{|l} 
Mother's Level Of \\
Education \\
\end{tabular}} & \multicolumn{2}{|c|}{$\begin{array}{l}\text { Households with Zero Private } \\
\text { Tutoring Expenditures }\end{array}$} & \multicolumn{2}{|c|}{$\begin{array}{c}\text { Households with Positive Private } \\
\text { Tutoring Expenditures } \\
\end{array}$} \\
\hline & Number & Percent & Number & Percent \\
\hline Illiterate & 970 & 90.23 & 105 & 9.77 \\
\hline Non-graduate & 209 & 91.27 & 20 & 8.73 \\
\hline Primary & 1,538 & 84.6 & 280 & 15.04 \\
\hline Middle & 183 & 75.93 & 58 & 24.07 \\
\hline High School & 254 & 69.78 & 110 & 30.22 \\
\hline University & 96 & 56.8 & 73 & 43.2 \\
\hline Masters & 2 & 100 & - & - \\
\hline Total in Numbers & 3252 & & 646 & \\
\hline \multicolumn{5}{|c|}{$\begin{array}{l}\text { Household Head's Level } \\
\text { of Education }\end{array}$} \\
\hline Illiterate & 193 & 91.09 & 17 & 8.01 \\
\hline Non-graduate & 160 & 93.57 & 11 & 6.43 \\
\hline Primary & 1,740 & 88.28 & 231 & 11.72 \\
\hline Middle & 359 & 79.96 & 90 & 20.04 \\
\hline High School & 480 & 77.67 & 138 & 22.33 \\
\hline University & 315 & 66.60 & 158 & 33.40 \\
\hline Masters & 5 & 83.33 & 1 & 16.67 \\
\hline Total in Numbers & 3252 & & 646 & \\
\hline
\end{tabular}




\begin{tabular}{|c|c|c|c|c|}
\hline \multicolumn{5}{|c|}{$\begin{aligned} \text { TABLE1: } & \text { MEANS AND STANDARD DEVIATIONS } \\
& \text { HOUSEHOLDS WITH ZERO PRIVATE TUTORING EXPENDITURES; } \\
& \text { NUMBER OF OBSERVATIONS }=3252\end{aligned}$} \\
\hline Variables & Mean & $\begin{array}{c}\text { Standard } \\
\text { Deviation }\end{array}$ & Minimum & Maximum \\
\hline Ln (Private Tutoring Expenditure) & 0 & 0 & 0 & 0 \\
\hline Ln (Total Household Expenditure) & 12.22 & 0.60 & 10.35 & 15.51 \\
\hline Household Head's Head Age & 41.64 & 8.31 & 24.00 & 97.00 \\
\hline Household Head's Age Square & 1802.74 & 763.55 & 576.00 & 9409.00 \\
\hline Household Head's Years of Education & 6.76 & 3.88 & 0.00 & 17.00 \\
\hline Mother's Years of Education & 4.26 & 3.72 & 0.00 & 17.00 \\
\hline Mother Works & 0.21 & 0.41 & 0.00 & 1.00 \\
\hline Single Mother & 0.05 & 0.21 & 0.00 & 1.00 \\
\hline Single Mother Works & 0.01 & 0.12 & 0.00 & 1.00 \\
\hline Urban Location & 0.81 & 0.39 & 0.00 & 1.00 \\
\hline Developed Street & 0.37 & 0.48 & 0.00 & 1.00 \\
\hline Squatter Settlement & 0.05 & 0.21 & 0.00 & 1.00 \\
\hline Own House & 0.62 & 0.48 & 0.00 & 1.00 \\
\hline Number of Children & 3.17 & 1.67 & 1.00 & 15.00 \\
\hline \multicolumn{5}{|c|}{$\begin{array}{l}\text { HOUSEHOLDS WITH POSITIVE PRIVATE TUTORING EXPENDITURES; NUMBER OF } \\
\text { OBSERVATIONS }=646\end{array}$} \\
\hline & Mean & $\begin{array}{c}\text { Standard } \\
\text { Deviation }\end{array}$ & Minimum & Maximum \\
\hline Ln (Private Tutoring Expenditure) & 9.89 & .942 & 6.39 & 13.33 \\
\hline Ln (Total Household Expenditure) & 12.64 & 0.57 & 10.97 & 15.17 \\
\hline Household Head's Age & 43.83 & 7.91 & 27.00 & 74.00 \\
\hline Household Head's Age Square & 1983.97 & 753.02 & 729.00 & 5476.00 \\
\hline Household Head's Years of Education & 8.98 & 4.31 & 0.00 & 17.00 \\
\hline Mother's Years of Education & 6.52 & 4.51 & 0.00 & 15.00 \\
\hline Mother Works & 0.24 & 0.43 & 0.00 & 1.00 \\
\hline Single Mother & 0.05 & 0.22 & 0.00 & 1.00 \\
\hline Single Mother Works & 0.01 & 0.10 & 0.00 & 1.00 \\
\hline Urban Location & 0.92 & 0.27 & 0.00 & 1.00 \\
\hline Developed Street & 0.59 & 0.49 & 0.00 & 1.00 \\
\hline Squatter Settlement & 0.02 & 0.16 & 0.00 & 1.00 \\
\hline Own House & 0.63 & 0.48 & 0.00 & 1.00 \\
\hline Number of Children & 2.51 & 1.20 & 0.00 & 10.00 \\
\hline
\end{tabular}

